\title{
Sõjamoonaga mängimine Eestis Teise maailmasõja ajal ja pärast seda: folkloristlik vaatenurk ${ }^{1}$
}

\author{
Astrid Tuisk \\ Eesti Kirjandusmuuseumi Eesti Rahvaluule Arhiivi teadur \\ astrid.tuisk@folklore.ee
}

\begin{abstract}
Teesid: Laste maailma ilmestas Teise maailmasõja ajal ja pärast seda sõjategevusega seotud keskkond. Sõda jättis jälje ka maastikule - veel mitu aastakümmet pärast Teise maailmasõja lõppu leidub mahajäänud sõjamoona.

Eesti Rahvaluule Arhiivi lastemängude kogumise võistlusele 2013. aastal kirjutasid seitse inimest sõjamoonaga mängimisest: padrunite lõkkesse viskamisest ja nendega paugutamisest, päris püssirohu kasutamisest susspüssides jne. Ka elulugudes meenutatakse sõjamoonaga tegutsemist. Neid mänge peavad mitmed kirjutajad ohtlikeks ja imestavad, kuidas nad lapsena ohtu ei tajunud. Nii tekib küsimus, kas sõjamoonaga tegutsemist saab üldse käsitleda mänguna, ning kui, siis mis liiki mängudega on tegu - kas sõjamoonaga mängimise saab lastemängude kontekstis paigutada näiteks paugutamismängude või ohumängude alla. Kontekstualiseerimist kasutades vaadeldakse artiklis, kuidas kirjutajad ise oma mängukogemust iseloomustavad, kas tegemist on konkreetsesse ajastusse ja keskkonda paigutatava tegevusega või saab seoseid luua ka mängimisega teistel ajajärkudel.
\end{abstract}

Märksõnad: elulood, kontekstualiseerimine, lastefolkloor, lastemängud, ohumängud, rahvaluule kogumine, Teine maailmasõda, 1950. aastad

Lastemängud, nagu lastefolkloor üldse, tugineb ühelt poolt traditsioonile, teisalt avaldub selle uuendusmeelsus ja variatiivsus, eri mänge kombineeritakse, segatakse ja töödeldakse ümber.

Lapsed on osalised nii täiskasvanute kui ka eakaaslaste kultuuris ja tõlgendavad täiskasvanute kultuuri loova jäljendamise kaudu (Corsaro 2005: 40-42, 121-148). Oma mänge mõeldakse välja või kohandatakse eakaaslastelt ja täiskasvanute maailmast. Soome uurija Marjatta Kalliala toob mitmeid näiteid sellest, kuidas mängukultuur üldisemalt on mõjutatud oma ajastust, ühiskondlikust ja kultuurilisest ümbrusest, muuhulgas ka ajaloolistest sündmustest. Nii muutusid pärast Nõukogude Liidu lagunemist 1990. aastatel vene laste mänguteemad ja mänguasjad kiiresti ja tuntavalt. Uusi teemasid ammutati 
Lääne televisiooniprogrammidest, miilitsate asemel said mängukangelasteks poodidesse müügile ilmunud Barbie-nukud ja Power Ranger mänguasjad. 1930. aastate Saksamaal oli tüdrukute unistuseks omada fašistliku Saksamaa sõdurivormis Käthe Kruse vabrikus valmistatud nukku. "Laste mängud kuuluvad oma ajastusse ja oma kultuuri hulka," võtab Kalliala kokku (Kalliala 2006: 23-25). Nii mõjutas ka Teine maailmasõda mitmel viisil sel ajal ja pärast sõda elanud laste mänge ja mängimist. Üks sõja jälgi, mis inspireeris lapsi mängule, seostub kergesti kättesaadava sõjamoonaga.

Eesti Kirjandusmuuseumi Eesti Rahvaluule Arhiivis korraldati 2013. aastal lastemängude kogumise võistlus. Sellest võttis osa 45 eri eas inimest, mitmete töödega saab tutvuda internetiaadressil: http://www.folklore.ee/ukauka/arhiiv/ exhibits/show/kogumisvoistlus_2013/terviktekstid (Uka-uka 2013). Meenutamise hõlbustamiseks oli koostatud küsitluskava. Selles küsiti peale mängukirjelduste ka lapsepõlve kohta laiemalt: paluti kirjeldada mängukeskkonda, mängupaika, -kaaslasi ja mängimise aega.

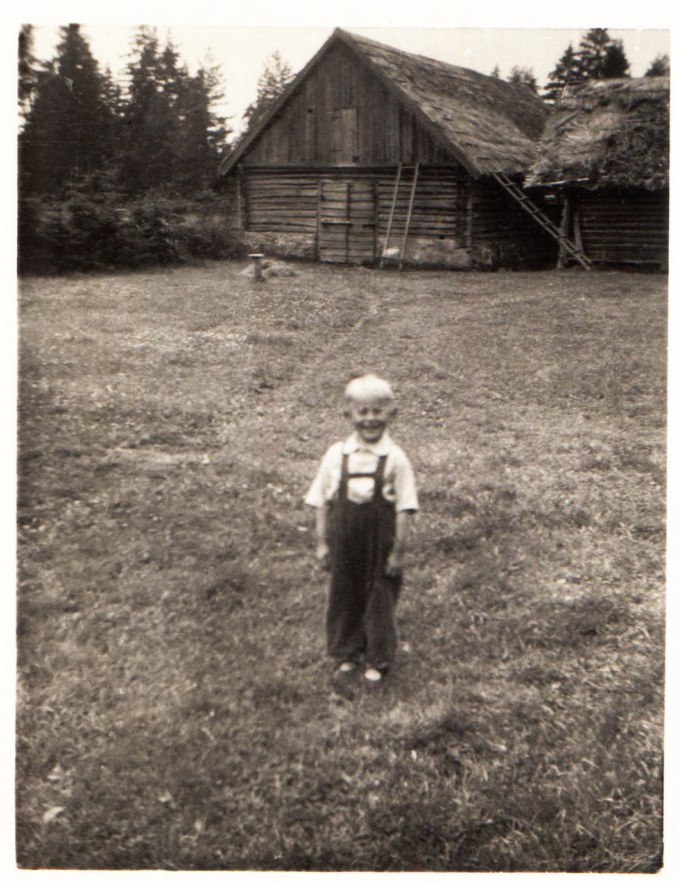

Foto 1. Lastemängude kogumise võistlusest osavõtja Tiit Birkan (snd 1938) oma vanaisa talu juures. Sillaotsa (Türi khk, Järvamaa, Pöiatu küla). Foto taha on kirjutatud: Sillaotsa pärisperemees Tiit. Foto 1940. aastate algusest. ERA, Foto 17937. 
Teise maailmasõja aegset ja järgset lahingutest mahajäänud sõjamoonaga mängimist meenutavad oma mälestustes aastatel 1927-1946 sündinud. 1920.1930. aastatel sündinud mäletavad ka sõja-aastaid, 1940. aastatel sündinute kirjutatu hõlmab aga põhiliselt sõjajärgseid mängukogemusi. Kirjeldatud on nii talulaste mänge ja mänguasju kui ka linnades ja asulates kasvanud laste mängumaailma. Kogumisvõistlusest osavõtjad olid kirjutamise ajal vanemad kui 60 aastat, enamasti juba pensionil, tööelust eemal. Mitmed neist on kirjutanud ka elulugusid ja mälestusi, osa neist on pikaaegsed rahvaluulearhiivi kaastöölised.

Selles artiklis vaatlen lähemalt sõjamoonaga mängimist. Kasutan väljendit “sõjamoonaga mängimine" seetõttu, et see hõlmab nii lõhkeainete ja laskemoonaga, aga ka laskeriistade ja muu mahajäänud sõjatehnika ja selle tükkidega tegutsemist.

Lahingutest mahajäänud lõhkeainete ja relvadega mängimine on teema, mida oma lapsepõlvest meenutavad seitse kirjutajat. Seda ei ole palju, kuid tõstan sellist mänguviisi esile põhjusel, et mitmesugustes allikmaterjalides (elulugudes ja mälestustes, ilu-ja ajakirjanduses) leidub sellestsamast ajastust rääkivaid episoode, kus puudutatakse laste kokkupuudet sõjamoonaga.

Samuti on Teise maailmasõja aegse ja järgse sõjamoonaga mängimise omakogutud materjali põhjal välja toonud etnoloog Helena Grauberg (Grauberg 2003). Eesti-Soome ühisprojektis "Children of Wartime" mainivad sõjamoonaga mängimist nii Eesti kui ka Soome informandid (Europaeus \& Põlluäär 2016: 17-19). Laste igapäevaelu sõja ajal, nende mängimist ja töötegemist on mälestustele tuginedes uurinud Soome teadlased: ka seal mäletatakse laskemoonaga paugutamist (Paksuniemi \& Määttä \& Uusiautti 2015).

2013. aasta lastemängude kogumise võistluse küsitluskavas ei olnud sõjamoonaga tegutsemise kohta eraldi küsimust. Lähtun hüpoteesist, et igasugust lõhkeainete ja muu sõjamoonaga tegutsemist ei saa alati mänguna määratleda, kuid siiski pidasid seitse kirjutajat ise sõjamoonaga tegutsemist mänguks, kuna kirjutasid selle lastemängude kogumise võistlusele. Vaatlen, kas sõjamoonaga mängimist saab ka uurijana käsitleda kui mänguliiki, kas ja missuguseid paralleele leidub sõjamoonaga mängimisele teiste mänguliikide seas.

Alljärgnevas on tegemist folkloristliku uurimusega, kus asetan sõjamoonaga mängimise kirjeldused teiste mängukirjelduste kõrvale, mängimise ja mängude üldisemasse konteksti.

Uurimismeetodina kasutan kontekstualiseerimist, vaadeldes allikmaterjali loomet arhiivi kogumisvõistluse korraldajate ja vastajate koostööna. Samuti kasutan rekontekstualiseerimist, asetades tekstid uude konteksti, võrreldes neid teiste lastemängudega (Bauman \& Briggs 1990: 66-72). Folkloristliku suunitlusega kontekstualiseerimist on Teise maailmasõja järgsesse perioodi 
asetuvatest vorstivabrikumuistendite analüüsil kasutanud Eda Kalmre (2007). Leian, et ka sõjamoonaga mängimine on tihedalt seotud just oma keskkonnaga - sõja- ja sõjajärgse ajaga Eestis. Arutlen, kas ja kuivõrd saab laskemoonaga mängimist vaadelda üldse mänguna, ja kui, siis mis mänguliigiga on sel kõige rohkem kokkupuutepunkte.

\section{Sõjamoonaga mängimise kirjeldused lastemängude kogumise võistluse kaastöödes ja elulugudes}

Sõjamoonaga mängimise kohta ei olnud küsitluskavas eraldi küsimust, nagu ei olnud spetsiaalselt küsitud ka sõjamängude kohta. Küsitluskava oli üles ehitatud nii, et esimestes punktides tuli iseloomustada mängukeskkonda, mängukaaslasi ja mängupaiku, edaspidi paluti kirjutada mängualustamissalme ning mängukirjeldusi, selgitada mängu käiku ja reegleid. Kuna küsitluskava järgimine polnud kohustuslik, siis alati seda ei tehtudki, mitmed kirjutajad koostasid essee või jagasid kirjutatu alapeatükkidesse nii, nagu neile oma töö seisukohalt parem tundus.

Et mängud paremini meenuksid, olid küsitluskavas ära nimetatud mänguliigid, näiteks palli-, jooksu-, viskemängud. Samuti oli küsitluskavas loetletud erinevaid kujutlus- ehk fantaasiamänge, nagu kodu, pood, arstimäng, nukkude ja autodega mängimine, kuid sõjamoonaga mängimist ei leidunud kummaski loetelus. Sellele vaatamata sõjamoonaga mängimisest kirjutati.

Sõjamoonaga mängimist kirjeldavad kolm 1940. aastatel sündinud naist. 1946. aastal sündinud naine räägib oma karjaskäimisest ja padrunite lõkkesse viskamisest, kirjeldades mänguseltskonda. 1945. aastal sündinud naine nimetab mängu "Sõjasaagiks" ning on paigutanud selle mängukirjelduste alla. Teist korda räägib ta padrunitega mängimisest küsitluskavale vastates punkti all, kus küsitakse tüdrukute- ja poistemängude kohta, nimetades padrunite lõkkesse loopimist poiste tegevuseks. Lastemängude kogumise võistlusel osales vaid üks 1940. aastatel sündinud poiss, nii ei ole võimalik selle materjali põhjal öelda, kas poiste meenutustes oleksid mängud sõjamoonaga suuremal määral esil. Eesti-Soome ühisprojekti "Children of Wartime" Eestist kogutud materjalide põhjal märgib Aivo Põlluäär, et laskemoonaga mängimist meenutasid just poisid (Europaeus \& Põlluäär 2016: 18).

1943. aastal sündinud naine toob sõjamoonaga mängimise välja sõjamängudest kõneldes, öeldes, et sõjamängudes kasutati päris laskeriistu ja lõhkeainet ning varuti püssirohtu, et oleks lõkke süütematerjali. Sõjamoona kasutamise sõjamängude mängimise käigus jätan hetkel vaatlusest kõrvale, kuna sõjamänge on nende mitmekesisuse tõttu mõistlik täiesti eraldi käsitleda. 
Ja lahti läinud lahingus paukusid ehtsad püssid küllaltki sageli... mõned õlavigastused löögist, mõned põletused püssirohuga näkku... [---] Ei mäleta suuri traumasid või hukkumisi laste hulgas, ehkki keegi päästeti uppumast, ehkki sõjamängud toimusid osaliselt lõhkeainetega, oli vigastusi vähe. (ERA, DK 134, $1<$ Kanepi khk, Krootuse (2013))

Sõjamoonaga mängimist meenutasid ka varasemal ajal sündinud. Nii kirjeldavad seda neli vastajat, kaks 1930. aastatel sündinud meest ja üks naine ning üks 1927. aastal sündinud mees. Teemat ei esine aga hilisemal ajal sündinute mängudega seotud mälestustes.

Sõjamoonaga mängimine ja vigasaamine on üks teema, mida sõja ajal ja pärast seda üles kasvanud inimesed oma elulugudes kajastavad. Nii toon võrdlusi ka Eesti Kultuuriloolises Arhiivis talletatud elulugudega. Neist mitmed on ilmunud eluloo-väljaannetes. Ootuspäraselt leiab temaatikat poiste elulugudes, mis on avaldatud kogumikes "Eesti rahva elulood" II osas: Avo-Rein Tereping, snd 1945, lk 338-349 (Hinrikus 2003) ja "Sõjas kasvanud poisid": Arvi Truu, snd 1938 (lk 60-61); Walter Kajak, snd 1932 (lk 147-148); Kalju Luuk, snd 1932 (lk 161-164, 170); Leo Laks, snd 1931 (lk 83); Heino Tooming, snd 1930 (lk 137) (Hinrikus 2011). Elulugudes jutustatakse sõjamoonaga mängimisest mitmel viisil. 1932. aastal sündinud Kalju Luuk kirjeldab isetehtud sussikute (susspüsside) valmistamist, aga ka põletushaavu näol ja kätel. Samuti on juttu omavahelisest võistlusest, kes julgeb lõkkele kõige lähemale jääda, kui sinna padruneid ja omavalmistatud lõhkekehi visatakse (Hinrikus 2011: 161, 170). Mahajäänud sõjavahenditega mängimist kajastatakse nii 1990. aastatel kirjutatud elulugudes (Mulla 2003: 116-117) kui ka neljas 2016/2017. aastal võistlusele "Eesti Vabariik 100. Minu elu ja armastus" saadetud töös (EKLA 350: 28, 120, 145, $179(2016 / 2017))$.

\section{Erinevaid viise sõjamoonaga mängimise kirjeldustes}

Mida mälestuste kirjutajad ise on mängimiseks nimetanud ja lastemängude kogumise võistlusele kirjutanud? Sõjamoonaga mängimisega seoses meenutavad kaks 1940. aastatel sündinud naist seda, kuidas karjas käies lõhkemata padruneid lõkkesse visati ja kuulatati, kui suur pauk tuleb. Kirjeldus toob esile pigem mängu toreduse, seda kirjeldatakse teiste lapsepõlvemängude seas.

Kuna pidin ka meie lehma karjatama kodust eemal (ja ka Jaani perel oli lehm), [---] Tegime lõket, küpsetasime kartuleid lõkkel ja sõjajärgsete lastena oli siin-seal padruneid, mida loopisime lõkkesse. Niipalju oli meil siiski mõistust peas, et panime piisavasse kaugusesse ühe paeplaadi püsti 
ja loopisime selle tagant vaadates ja kuulates, kelle padrun kõvema paugu teeb. (ERA, DK 127, 3 (3.2) < Märjamaa, Haimre k)

Mõlemad tüdrukud paigutavad laskemoonaga mängimise konkreetsesse aega "sõjajärgsesse aega", "1950. aastatesse”. Kuid mõlemad toovad välja veel ühe aspekti - selle tegevuse ohtlikkuse. Hinnang, et mäng oli ohtlik, on tagantjärele antud. Kas seda ohtu ise tookord hoomati või ei, kirjeldatakse erinevalt. Arvatavasti mängis selles oma osa ka lapse vanus: nooremana ei osatud karta. Nii väidetakse ühes lapsepõlve mängimise kirjelduses, et sõjamoonaga mängimisel ohtu ei tuntud, samamoodi imestatakse teises oma hulljulgust.

Poisid korjasid padruneid ja muid sõjajäänukeid ja kui oli paras ports koos, tehti lõke üles ja visati need sinna sisse. Tuli päris kõva tulevärk. Õnn, et keegi surma ja haavata ei saanud. Ükskord küll miski riivas õe jalga ja verigi tuli välja, kuid seda ei pannud keegi tähele. Ohutunne puudus täielikult. Siiski üks poiss leidis ja hakkas mingit mürsku või miini lahti harutama ja see lõhkes ning viis minema tema parema käe sõrmed ja näkku tulid sinised armid. (ERA, DK 106, 5 (6) < Valga linn)

Sama naine märgib, et sõjasaagiga mängimist hoiti täiskasvanute eest salajas. Kuid üks (juba eelpoolnimetatud 1945. aastal sündinud kirjutaja) ja teine (1932. aastal sündinud naine) nimetavad sõjamoonaga mängimise eest karistada saamist. Saaremaal kasvanud naine (snd 1932) meenutab, kuidas ta vennad salaja padrunitega mängisid. Saksa okupatsiooni ajal oli isa koju toonud kastitäie padruneid. Pärast seda, kui üks vendadest kergelt vigastada sai, peideti padrunid ära. Mälestustes on juttu küll sellest, et poisid kartsid keretäit, kuid kas see ka saadi, ei selgu. Samuti mäletab naine kohta, kus vennad padrunitest saadud püssirohuga pauku tegid - tuuliku juures, sest seal oli selleks sobiv kivi, kuhu püssirohi peale kallati ja teise kiviga selle pihta löödi (EFA I 169, 1/30 < Jämaja khk, Rahuste k). Sama, kuidas poisikesed vanemate kivide lõhkumiseks varutud padruneid varastasid, meenutatakse ka elulugudes (Mulla 2003: 117). Kirjutaja on kauaaegne Eesti Rahvaluule Arhiivi kaastööline ning oskab tähelepanu pöörata detailidele ja faktidele - mängijad, mängimise aeg ja koht. Vendadega juhtunust kirjutab ta nn Saksa aega meenutades (tema töö on üles ehitatud kronoloogiliselt). Vendadest ja nende ühistest tegemistest on kaastöös juttu mitmes kohas. Ta annab oma võistlustöös ülevaate sellest, kuidas lapsena mängiti, toodud näide leidub teiste mängude seas. Lõigu lõpetab ta lausega, milles ta poiste tegevuse kui mängu küsitavusse seab: "Papa pani need padrunid siis poiste eest peitu. Oli "see” mäng läbi” (EFA I 169, 8/9 (2013)).

Meenutustest selgub, et innuga mängisid sõjamoonaga poisid, kes olid mängueas just siis, kui lahingutegevus rullus üle Eesti, seega siis 1920. aastate lõpus ja 1930. aastatel sündinud. Nagu eelnevalt refereeritud naise mälestustes, nii 


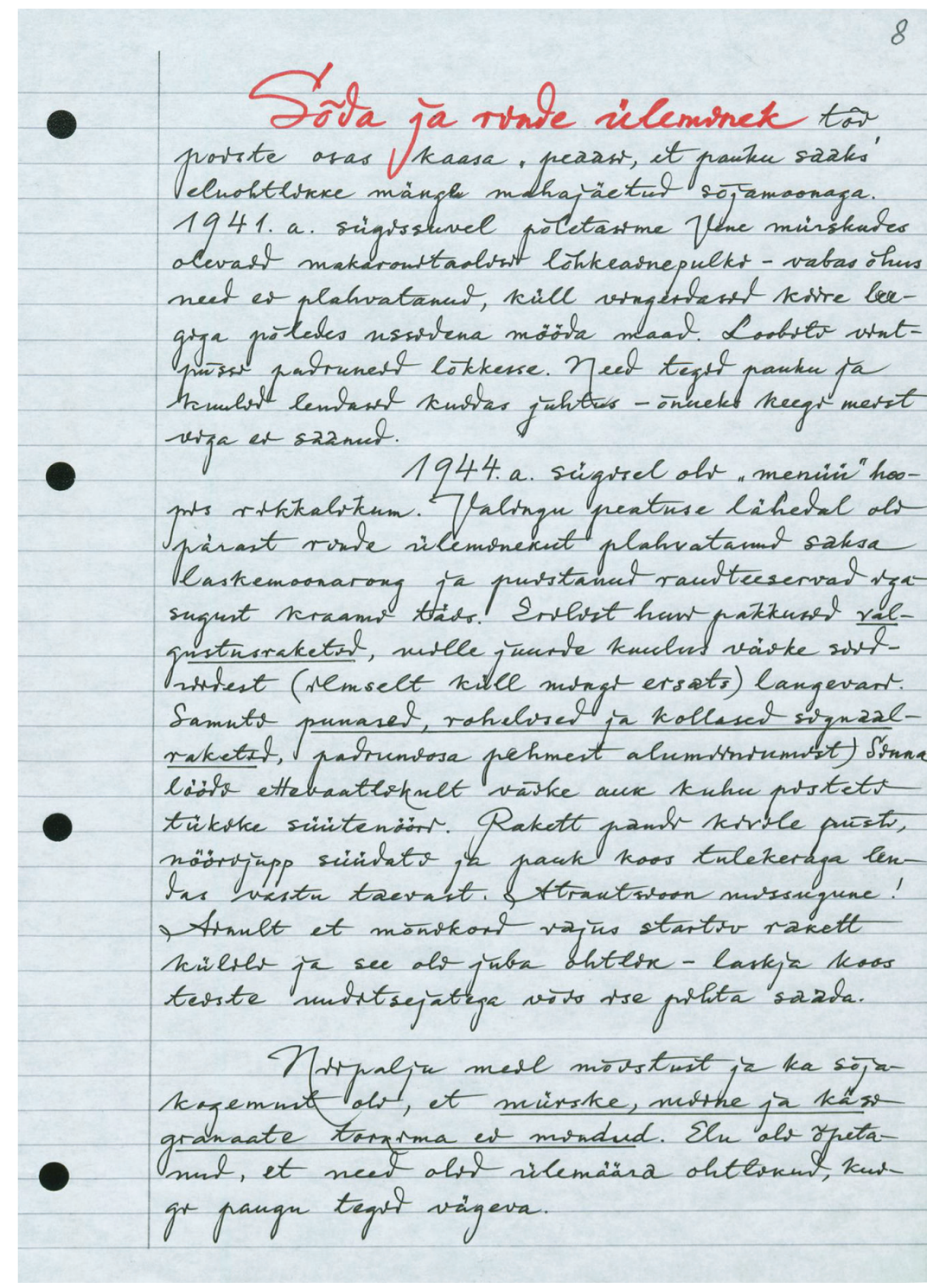

Foto 2. Lehekülg Hillar Palametsa (snd 1927) lastemängude kogumise võistluse kaastööst. EFA I 168, 151 (2013).

ka siin meenutatakse mitte sõjajärgseid, vaid just sõjaaegseid sündmusi. Nende mälestustes pühendatakse sõjamoonaga mängimisele pikemaid lõike. Samas tõdetakse ka nendes kirjutistes sellise mängu ohtlikkust. 1927. aastal sündinud 
mees: "Sõda ja rinde üleminek tõi poiste osas kaasa "peaasi, et pauku saaks" eluohtlikke mänge mahajäetud sõjamoonaga.” (EFA I 168, 151 < Tallinna 1)

Oma kogemustele tuginedes võrdleb ta sõjamoona, mida 1941. ja 1944. aastal oli võimalik leida, öeldes, et 1944. aastal oli “"menüü” hoopis rikkalikum”. Niisiis on sõjamoonaga mängimisel märkimisväärne seos mängija sünniaastaga: sellist "menüüd", mida said kasutada Teise maailmasõja ajal kasvanud poisid, ei olnud enam saada 1950. aastatel. 1950. aastate alguseks jõudsid demineerijad ja minöörid ohtlikumad kohad läbi käia ning lõhkekehad kahjutuks teha või ära korjata (Kirm \& Voltri 2016: 27). Mitmetes lahingupaikades ja sõjamoonaladude kohtades võis sõjamoona leida ka hiljem. Ida-Virumaal Sillamäel kasvanud Andrei Hvostov meenutab Sinimägesid kui potentsiaalset kohta poisikestele lõhkeaine saamiseks veel 1960. aastate lõpus, 1970. aastate alguses (Hvostov 2014: 127-128). Lõhkekehasid tuleb välja üle kogu Eesti tänapäevani. Eespool mainitud 1927. aastal sündinud mees väidab, et vähemalt mõningal määral oldi ohust teadlikud, aga tema oli 1944. aastal juba kas 16- või 17aastane ja mobiliseerimisest pääses oma sõnade järgi "üle noatera":

Niipalju meil mõistust ja ka sõjakogemust oli, et mürske, miine ja käsigranaate torkima ei mindud. Elu oli õpetanud, et need olid ülemäära ohtlikud, kuigi paugu tegid vägeva. (EFA I 168, 143, $151<$ Tallinna 1)

1932. aastal sündinud mees kinnitab oma eluloos hoopis vastupidist: tema väitel mindi järjest uljamaks ja riskialtimaks (Hinrikus 2011: 163). Hulljulgeid tegusid, mida sõjatehnika, laskeriistade ja laskemoonaga tehti, mainib ka Valgas kasvanud mees (snd 1930). Ta toob välja laskemoonaga mängimise keelamise ja õnnetused. Ta arutleb selle üle, miks poisid ikkagi seda tegid: "Need (purustatud sõjatehnikat, laskeriistad ja lõhkeained) lausa ahvatlesid poisse nendega mängima. Ja kas siis on üldse poisse, kellele ei meeldiks paugutamine, tulevärgi tegemine või märki laskmine?" (ERA, DK 121, $3<$ Valga 1). Niisiis toovad mõlemad mehed välja, et laskemoonaga mängimise üheks eesmärgiks oli "suur tulevärk" ja kõva paugu tegemine. Samuti tõstab kirjeldaja esile tegevuse nauditavust: see meeldis poistele. Poisid küll teadsid, aga ei hoolinud sellise tegevuse ohtlikkusest:

Mis sellest, et kõige selle ohtlikkusest oldi meid hoiatatud ja iga pidi ka avalikult ja kurjalt keelatud. Ei hirmutanud meid ka lähedaste ja tuttavate koolipoistega toimunud tõsised õnnetused.

Ta räägib oma koolikaaslastest, kellest üks sai lõhkekeha plahvatuses surma, teine vigastada ning oma ülikooliaegsest parimast sõbrast, keda oli samuti lõhkekeha vigastanud. Lõigu lõpus annab ta oma täiskasvanu hinnangu neile mängudele: 
Kõhedusega meenub mulle veel praegugi, milliseid hulljulgeid tegusid sai tol ajal tehtud nii püssirohu kui ka lõhkekehadega. Tuleb tänada saatust, et need "mängud" minu jaoks õnnelikult lõppesid. (ERA, DK $121,3<$ Valga 1 )

Oma suhtumist tõstab mees esile (nagu tegi seda ka 1934. aastal sündinud naine), asetades sõna "mängud" jutumärkidesse, nii et lugeja võib ise arvata, kas neid tegevusi saab mängudeks pidada ja olid need üldse lastele kohased mängud. Huvitav on veel see, et mida poisikesed siis täpselt tegid, me teada ei saagi.

On selge, et mänge lõhkeainete ja muu sõjamoonaga meenutatakse lihtsalt kui lapsepõlvemänge. Sõjamoonaga mängimine võib olla paigutatud konkreetsesse aega, öeldes, et tutvustatakse sõjajärgset aega või sõja-aastaid. See ei olnud kõige tavalisem laste tegevus, see erineb teiste põlvkondade lapsepõlveajast ning väärib seega lastemängude töös äramärkimist.

Soome lapsepõlvemeenutuste põhjal pauku tegevate vahenditega mängimist käsitledes toob Pirjo Korkiakangas välja, et täiskasvanutele on meelde jäänud mängud, kus tehti kõige suuremat ja kõvemat pauku, ning sageli liitub meenutamisega ka hoiatus, et need juhtumid võisid kurvalt lõppeda. Mälestustes analüüsitakse, põhjendatakse ja võetakse vastutus selle eest, et tegemist oli ohtliku tegevusega, millest ehk lapsena ei saadud lõpuni aru (Korkiakangas 1996: 258-259, 260-261). See võibki olla üheks sõjamoonaga mängimise meenutamise põhjuseks: täiskasvanuna tagasi vaadates hinnatakse selline tegevus ohtlikuks ning seda meenutatakse kui riskantset ja hulljulget tegevust lapseeast. Sõjamoonaga mängimise kirjeldustes siin analüüsitavas aineses pööratakse tähelepanu ka ohule: lapsena ei adunud nad ohu suurust, aga leidub ka vastupidiseid seisukohti, et osati ohtu hinnata või oldi lihtsalt uljad ega hoolitud sellest. Nii võib sõjamoonaga mängimise meenutamisel olla esiplaanil siingi selle ohtlikkuse rõhutamine, aga ka lugejatele oma uljuse ning uudishimu presenteerimine, ehk kerge uhkustunnegi: mida me kõik lapsena ära ei teinud.

Lõhkeainete ja sõjamoonaga mängimise ohtlikkust ega ka isiklikku kokkupuudet nendega vigasaamistest ei maini Väike-Maarja lähistel 1932. aastal sündinud ja Võnnusvere küla taluperes kasvanud mees. Kui tema loetleb mänge ja tegevusi, mis lapsepõlvest meenuvad, on teiste mänguliikide kõrval (lauamängud, sõnamängud, laskemängud, mängud liivaaukudes jne) nimetatud ka sõjamaterjalidega mängimist:

Sõjamaterjalidega mängimine: käsigranaatide lahtiurkimine, lõhkekapslitega paugutamine, nendega dünamiidiga plahvatuste tegemine, mürskude lahtitagumine saksa Äntu metsa laskemoonaladudes. (EFA I 168, 107 < Väike-Maarja khk, Võnnusvere k) 
Mänguliikide loendis leiduvad ka sellised punktid nagu sõjamängud ja susspüsside tegemine. Sõjamängude punkti alla on ta paigutanud kepist püssidega üksteise tagaajamise. Ta kirjeldab ka seda, kuidas sõjamoona kasutati ohutul moel, lihtsalt mänguvahenditena:

Püssipadrunite kogumine ja lahtikoukimine, vastastikune padrunikestade pikaliajamine kuullaagri kuuliga, tikutoosidest laevade torpeteerimine sama kuuliga. (EFA I 168, 107 < Väike-Maarja khk, Võnnusvere k)

Mitmed meenutajad mainivad mänguasjade vähesust. Aega veedeti mänguasjadega, mida meisterdati ise kätte juhtuvast materjalist, näiteks papist ja tühjadest tikutoosidest või looduslikest vahenditest (EFA I 168, 143/55 < Tallinna linn; ERA, DK 115, 2-3 < Türi khk, Kurla k; EFA I 169, 37 < Muhu khk; EFA I 169, 106 < Räpina khk, Kirmsi k jt). Nii võisid sõjast jäänud tehnika ja selle tükid lastele mänguvahenditena teretulnud olla. Ühes oma ajaleheintervjuus räägib sama meesterahvas oma tehnika- ja elektrihuvist, edaspidi saigi temast elektriinsener. Ta kuulas suure huviga isa mälestusi Vabadussõjast: "Peagi oli sõda siinsamas meie ümber. Poistele hakkasid näppu mitmesugused relvad, padrunid ja lõhkeaine. See oli nagu eriala omandamine. Erilist huvi pakkusid allatulistatud lennukid" (Raigna 2012). Väljendit “poiste huviobjekt" kasutab oma eluloos ka 1932. aastal sündinud mees:

Sakslaste taganemise eel nende õhkulastud laskemoonaladude jäägid Emajõe ääres saevabriku saepurusel väljakul olid peale sõda poistele huviobjektideks. Jääb imestada, et me hoogsa paugutamise juures rängemalt vigastada ei saanud (kergemalt küll). (EKLA 350, 28 (2016/17))

Mitmesuguse sõjatehnikaga ja lahingumoonaga tegelemise kaudu said tehnikahuvilised poisid oma tehnikakirge rahuldada. Sellises kontekstis saab paremini mõistetavaks mehe vaatenurk sõjamoonaga tegutsemisele, sest oma töös ta otseselt sõjamoonaga mängimisele hinnangut ei anna. Oma lapsepõlvemängudele antud kokkuvõttev hinnang tõstab esile maal kasvamise paremust ning lapsepõlvemängude (mitte aga mänguasjade!) kirjusust.

Näib, et tänapäeval lapsed ei mängi nii mitmekesiseid mänge kui minu koolipõlves. Linnas on teised mängud. Maaelu on kadumas. Lapsed maal vaid suveti oma vanavanemate juures. Televiisor, arvuti ja telefon võtab kogu vaba aja neilt ära. Samal ajal piirab liikuvust ja mõttemaailma. (EFA I 168, 108 < Väike-Maarja khk, Võnnusvere k)

Selles tsitaadis on rõhutatud laste fantaasiarikkust. Oma kaastöös kirjeldabki ta üldjuhul mängude kõrval selliseid tegevusi, mida ise välja mõeldi ning milleks sageli ka ise mänguvahendeid valmistati, nagu näiteks liivaaukudes mängimine 
nii, et klotsidel on peal pulgast kahurid, liivapallidega pommitamine, värviliste kivide otsimine jne. Sõjamoona ja -tehnikaga tegutsemise kirjelduses tõstetakse esile loovust, oskust mänguvahenditena tarvitada kõike, mis võimalik oli. Nii iseloomustab sõjamoonaga mängimine selles Virumaa mehe töös mitte lõhkeda võivat sõjavahendit, vaid mänguviisi, mis rikastas laste mängumaailma. Mahajäänud sõjamoonast sai valmistada mänguvahendeid, ühtlasi tõukus neist uusi ideid mängimiseks.

Ka lastemängude uurijad toovad välja selle, et sel ajal ei olnud palju mänguasju ega ka vahendeid, millest neid valmistada, samas oli sõjamoon küllalt kergesti kättesaadav. Soome laste sõjaaegse elu-olu uuringus märgitakse, et mängiti nii päris relvade, lõhkemoona kui ka laskemoona osade ja tükkidega ehk kõigega, millega oli võimalik, kuna spetsiaalseid mänguasju oli vähe (Paksuniemi \& Määttä \& Uusiautti 2015: 121). Valgas kasvanud naine sõnastab mänguasjade vähesuse küsimustiku selle punkti all, kus küsiti üksinda mängimise kohta:

Aega üksi mängimiseks praktiliselt ei olnud. Kui oligi tegevustest vaba hetk, lugesin raamatuid. Unistasin ajast, kus oleks rohkem süüa, riideid ja mänguasju. Nagu muinasjuttudes. (ERA, DK 106, 5 (6) < Valga linn)

2013. aasta lastemängude kogumise võistluse kirjeldustes kajastatakse sõjamoonaga mängimist mitmel viisil: laste seisukohalt kujutatakse rõõmu ja leidlikkust, aga ka nõutust - täiskasvanute vaatepunktist olid mängud ohtlikud. Sõjamoonaga mängimise kirjeldustes avaneb lastefolkloori rikkus: laste võime oma fantaasiat rakendada, seda olude ja võimalustega kohandada ning erinevaid vahendeid oma tegevustes loovalt kasutada.

\section{Sõjamoonaga ei mänginud kõik lapsed}

Lastemängude kogumise võistlusest osavõtjate hulgas on neid, kes ei maini oma võistlustöödes lõhkeainete ja sõjamoonaga mängimist. Võib olla, et osa kirjutajaid ei mäleta seda oma lapsepõlvest või ei pööra sellele nii suurt tähelepanu. Kindlasti ei pea üks osa kirjutajaid sellist tegevust mänguks. Kuid võrdlusmaterjali toel saab välja tuua ka põhjusi, miks sõjamoonaga tegutsemist ei taheta meenutada, miks seda ei peeta mängudest kõneldes oluliseks.

Nii lõhkeainete plahvatustes kui ka relvadega mängimisel juhtus lastega mitmeid ränki õnnetusi. Lapsed said õnnetustes kannatada ka tahtmatult, mitte sõjamoonaga mängides, vaid juhuslikult, näiteks kogemata lõhkemata miinile astudes. Õnnetustes vigasaanute lähedastele ning nende pealtnägijatele mõjusid need kindlasti šokeerivalt, aga ehmatada võisid need ka teisi tollaseid 
koolilapsi. 1935. aastal sündinud mees räägib koolipoistega juhtunud õnnetusest, mis teda puudutas. Ta toob selle õnnetuse põhjuseks, miks ta sõjamänge ei armastanud: "Sõjamänge ei mänginud. Seda sõda oli niigi küll” (ERA, DK 173, $10<$ Avinurme (2013/14)).

Ühele osale lastest ei pakkunud lõhkeainete jm paugutusvahenditega tegutsemine lihtsalt huvi, näiteks ei meeldinud neile paugutamine (vt nt ERA, DK 481, 1). Ajakirjanik Toivo Tootsen (snd 1943) märgib oma intervjuus, et temas ei olnud sõjamoonaga mängimiseks vajalikku uljust ning meelsamini luges ta hoopis raamatuid:

Mänguasjaks olid pigem kahuri küljest pärit sihikud, padrunikestad ja susspüssid. Selline poisikeste sõja-aegne värk, kuigi mina nii väga seiklushimuline ja riskialdis polnud. Teised poisid küll. Panid miini kaltsu sisse, et ta kohe ei plahvataks, ja viskasid siis lõkkesse. Aga mina nende ohtlike mängude harrastaja ei olnud, mind köitsid ikka rohkem raamatud. (Kulli 2013)

Et teada saada kõigis õnnetustes vigasaanud ja elukaotanud laste üldarvu, konsulteerisin ajaloolaste, Eesti Sõjamuuseumi teadurite Lauri Vahtre ja Peeter Kaasikuga. See arv ei ole hetkel teada, ka ei ole vastavad allikad, kust sellist arvu leida, läbi töötatud. Kodu-uurijad Taivo Kirm ja Ilmar Voltri on Tartumaa Kuuste valla Sillaotsa, Tuigo ja Sipe kooliajaloo kohta käivate dokumentide ning sel ajal elanud inimeste mälestuste põhjal kindlaks teinud, et piirkonnas sai mahajäänud sõjamoona tõttu vigastada viis ning elu kaotas seitse poissi. Lisaks sai mahajäetud laske- ja lahingumoona plahvatustes viga ka täiskasvanuid ja hukkus koduloomi (Kirm \& Voltri 2016: 26-27).

Päästeamet on avaldanud andmeid hilisema aja kohta. Tänapäeval ei ole oht sugugi kadunud, sest sõdadest pärit lahingumoona leidude arv püsib väga suurena - keskmiselt ligi 3000 lõhkekeha aastas ning üks osa neist on plahvatusohtlikud tänaseni (Päästeamet 2018). Kui arvestada ülaltoodud ühe paikkonna kohta käivaid arve, aga ka teema sagedust nii minu kogutud mälestustes kui EKLAs säilitatavates elulugudes, võib arvata, et kannatada saanud laste arv sõjajärgsel ajal oli märkimisväärne.

Sõjamoonaga mängimist nähakse olulise osana oma lapsepõlvetegevustest. Mitmed meenutajad nimetavad seda otsesõnu "mänguks", teised teevad seda ülekantud tähenduses. Juttu surmasaamistest neis vaadeldavates mälestustes ei ole, küll aga kirjeldatakse vigastusi. Sõjamoonaga kokkupuutumist ei meenuta oma lapsepõlvest sugugi kõik sõja ajal ja pärast seda üleskasvanud, näiteks ei taheta seda meenutada õnnetustega seoses või seetõttu, et ei hoolitud sellisest tegevusest. 


\section{Paugutamine vanemas mängutraditsioonis}

Kuna laskemoonaga mängimise üks eesmärk on paugutegemine, võib paralleele tõmmata sõjamoonaga paugutamise ja teiste mitmesuguste erinevate vahenditega paugutamise vahele. Vaatlen paugutamist laste tegevusena, jättes täiskasvanute tegemised, näiteks kivide lõhkamine, hüljeste küttimine või aupaugu laskmine vaatlusest kõrvale. Ka näiteks usundilise taustaga paugutamisel on pikem ajalugu. Nii on uusaastaööl lärmitsetud ja paugutatud tõrjemaagilisel otstarbel, kurjade jõudude eemale peletamiseks, paugutamisega saluteerimisest on Eestis teateid alates 1930. aastatest (Hiiemäe 1999: 12).

Laste tegutsemine lõhkeainetega, aga ka mitmesuguste erinevate püsside ja laskeriistadega, ei ole ainult sõjaaegne ja -järgne eriteema. Siis lihtsalt leidus sõjamoona rohkem ning see oli lastele hõlpsamalt kättesaadav. Eesti Rahva Muuseumist pärineb aga teade Esimese maailmasõja ajast, selle on üles kirjutanud Eha Leek, jutustanud Kirill Sepp Järvekülast, Jüri kihelkonnast:

Peale I Ilmasõda oli lastud padrunid kõikjal vedelemas. Padrunile viiliti auk otsa, isa järelt näputäie püssirohtu sisse, peale veel pudistati tuletikkude otsast väävelt. Kui püssirohtu ei saanud, läks vaja tikutoosi täis tikkudel väävel otsast võtta. Pika kepi otsa, näpitsate vahele seoti padrun kinni traadiga. Paremas käes oli siis see püss, padruniga ots ülespoole, pahema käega tõmmasid tikust tuld, sü̈̈tasid väävli; käis pauk ja sädemed muudkui lendasid. Püssi pidid kohe kõrgele peakohta tõstma, muidu põletas silmad. (KV 638, 54 (1975-1990))

Vanemate järelt püssirohu võtmisele viitab ka Jaan Kross raamatus "Vastutuulelaev". Peategelane Bernhard Schmidt meenutab oma 19. sajandi lõppu jäänud lapsepõlvest Naissaarel, kuidas ta raketti hakkas ehitama: poisid leidsid raudtoru, kalurite ja talumeeste varust saadi püssirohtu ning süütenööriga süüdatav rakett oligi valmis. Kuna rakett ei süttinud, läks poiss lähemale, et asja uurida, ning rakett plahvatas, õnnetuses kaotas poiss parema käelaba (Kross 1987: 18-20, 132-133).

Mitmesuguste vahenditega mängu-paugutamise kohta leidub viiteid Eesti Rahvaluule Arhiivi kogudes. Paugutusvahendeid tehti näiteks paberist (nn paberist plaks või pauk) või kasutati puulehtede abi. Üheks viisiks, kuidas lapsed paugutasid, on söepauk, just sellist pealkirja kannab alajaotus mängude kartoteegis. Sageli tehti söepauku karjas. Märja kivi peale pandi põlev söetükk ja teise kiviga selle peale lüües kõmatas pauk. Karjas paugutamisel oli oma otstarve, nii aeti metsloomi eemale, aga ka meelelahutuslik tagapõhi - pauguga ehmatati unest üles magamajäänud õitsilisi (Hiiemäe 1998: 189). Samuti valmistati mitmesuguseid laskeriistu, nagu näiteks ragulkasid või susspüsse. 
Sosspüssid (ka sutspüss, sutsakas, suss) on torust ja puupärast koosnev tikuga süüdatav laskeriist (ÕS 2013). Püsside tegemine ja nendega mängimine on lai teema, mida selles artiklis käsitleda ei jõua. Püssidega seoses saab vaadelda laskemoonaga mängimist kui sõjamängu, kus päris sõjamoona kasutatakse laskmiseks, näiteks isetehtud sosspüssides, nagu artikli esimesest näitetekstist selgub.

Soomes eri aegadest pärit lapsepõlvemälestusi analüüsinud Pirjo Korkiakangas toob esile, et mitmesuguste isetehtud laskeriistade (nt susspüsside, vibude) valmistamine ja püssirohuga paugutamine levis ühelt poistepõlvkonnalt teisele, 20. sajandi esimese poole agraarmiljöös võisid vanemad õpetada lapsi laskeriistu valmistama ja neid käsitsema (Korkiakangas 1996: 260). Ühelt poolt on sõjamoonaga mängimine seotud konkreetse ajastuga, teisalt leidub erinevate ajastute laste tegevustes mitmeid ühisjooni.

\section{Ohumängud ja teised riskile ülesehitatud mängud}

Riskile ja hulljulgusele ülesehitatud mängude näiteid leiab mitmes lastemängude käsitluses. Neis leidub viiteid väljakutse-mängudele (daring games) (Opie \& Opie 1984: 263); ohtlikele mängudele (dangerous games) (Tucker 2008: 36-37), samuti riskimängudele. Iona Opie ja Peter Opie iseloomustavad neid kui mänge, mis kutsuvad üles üksteisele oma julgust ja võimeid demonstreerima (Opie \& Opie 1984: XXIV). Siia kuuluvad sellised tegevused nagu autode (hobuste, rongide) eest üle (raud)tee jooksmine, võitja on see, kes julgeb liiklusvahendi eest kõige lähemalt üle tänava (või raudtee) joosta või keelava valgusfooritulega üle tänava minna; erinevad visked nugade või kääridega jne. Iona ja Peter Opie peatuvad oma käsitluses ka õnnetustel, mis nende mängude käigus on juhtunud (Opie \& Opie 1984: 263-274).

Sõjast jäänud lõhkeainete ja laskeriistadega mängimist seob nende ohumängudega just see, et nendega on seotud risk. Kuigi vigastusi võib saada mitmetes mängudes, on nende mängude eesmärk otseselt balansseerimine piiril, kas tekib vigastusi või mäng sooritatakse edukalt. Kõige halvema stsenaariumi korral võivad need mängud lõppeda mängija surmaga. Lastele ja noortele meeldivad ohtlikud mängud sellepärast, et nad panevad neis proovile oma oskused ja julguse. Paraku ei ole neil sellist elukogemust nagu täiskasvanutel ning alati ei oska nad pädevalt hinnata mängutegevuse riski, seetõttu võib mängimisele ajendada rohkem uudishimu kui uljaspäisus (Opie \& Opie 1984; Tucker 2008: 36-37).

Lastefolkloori uurijad liigitavad need laste tegevused mängude alla seetõttu, et sarnastena ringlevad mängud läbi aja ja maade, neil on kindlad reeglid ja 
nimetused. Üks tuntuimaid on mäng, kus raudteerööbastele heidetakse pikali nii, et pea jääb rööbastele, ja viimasel hetkel hüpatakse rongi eest ära. Mäng on teada näiteks nimetustega "Railroad Chicken", "Last Across", "Chicken" ning seda on kirjeldatud juba 1883. aastal kogumikus "Games of American Children” (Opie \& Opie 1984: 269-272; Tucker 2008: 78-79).

Sarnaseid mängukirjeldusi leiab ka rahvaluulearhiivi kogudest, üksikuid teateid on võidu hobuste eest üle tee jooksmisest või hobuste kõhu alt läbi pugemisest, viimasest kirjutati ka eluloovõistlusele "Minu elu ja armastus":

Sellest ajast on mul meeles, et elasime Narvas ühe suure kivimaja teisel korrusel. Maja juures oli sisehoov, kus teiste majaelanike lastega koos mängisime. Mäletan veel, et olin ainuke nende seas, kes julges väravast välja minna tänavale ja üle tänava joostes, pugeda liikuvate voorimeeste hobuste kõhu alt läbi. Õnneks vanemad pereliikmed seda ei teadnud. (EKLA 350, 87 (2016/17))

2013. aasta lastemängude kogumise võistluse kirjeldustes leidub viimasel hetkel liiklusvahendi eest üle tee jooksmisest selline näide. Jutustaja, 1951. aastal sündinud naine ise ei pea tegevust mänguks, vaid pigem lolluseks. Sellele vaatamata kirjutab ta sellest oma kooliaja mänge tutvustades:

Esimesest klassist olime internaadis kahekesi ühe elava tüdrukuga, kes oli oma teismeliselt vennalt õppinud mitmesugust "elutarkust". Neid lollusi õpetas ta mullegi. Näiteks mõtles ta välja sellise mängu: jookseme autode eest üle tee, vaatame, kes julgeb autole ligemal joosta. Jooksimegi, aga vahele jäin mina, kui Willise juht kinni pidas ja asi lõppes ema koolikutsumisega (mis jäi ainsaks korraks minu elus). (EFA I 168, 24/75 < Iisaku khk, Lõpe k (2013))

Karistuse kartuses tegevuse vanemate eest varjamine on samuti joon, mis seob ohumänge ja sõjamoonaga mängimist. Ohtlike vahenditega, terariistade ja tulega (nt tuletikkudega, aga ka kirve või noaga) mängimine on ala, mida lapsevanemad Soome agraarmiljöös eriti noorematele lastele keelasid. Sageli olid vanemad lapsed need, kes pidi nooremaid valvama ja ka ohutuse tagama (Korkiakangas 1996: 265-267).

Eesti meediasse jõudis liiklusvahendi eest üle tee jooksmise mäng nimega “Jookse või sure" 2017. aastal. Sotsiaalkindlustusameti lastekaitseosakond ja Politsei- ja Piirivalveameti veebikonstaabel tegid ühise pöördumise, et lapsevanemad ja õpetajad oskaksid ohtlikke väljakutsemänge ära tunda ja neile õigel ajal reageerida. Pöördumist jagati nii sotsiaalmeedias kui kodulehtedel, näiteks Tallinna linna kodulehel (https:/www.tallinn.ee/est/Uudis-Internetislevivad-ohtlikud-valjakutsemangud-lastele - vaadatud 04.07.2018). Samal ajal 
kajastati meedias vähemalt kolme päriselt aset leidnud juhtumit (Laine 2017; Michelson 2017; Harju Elu 2017).

Tänapäevaseid ohumänge eristab varasematest see, et need esinevad nn väljakutsete kujul ja levivad ekraanimeedia toel kiiresti. Samuti see, et sageli tegevust filmitakse ja video riputatakse sotsiaalmeediasse. Eestis on Iti-Liis Orro kirjutanud seminaritöö kontrollitud hingamise ehk lämmatamis- ehk minestamismängu kohta. See on mäng, mille eesmärgiks on osaline või täielik teadvusekaotus, millega kaasneb lühike eufoorialaadne tunne. Seda kutsutakse esile mitmel moel, kas midagi kaela ümber või rinnakule surudes, kuid kõikide võtete aluseks on hapnikupuuduse tekitamine ajus (ajuhüpoksia). Töö autori sõnul on mäng Eestis levinud 2000. aastatel ning toonud kaasa ka surmajuhtumi (Orro 2013). Oma töös peatub Iti-Liis Orro ka põhjustel, miks seda mängu mängitakse. Enda küsitlusele ning teiste uurijate järeldustele tuginedes toob ta esile järgnevad põhjused: kaif ning sellest tulenev mõnutunne, mida teadmatuse tõttu usutakse olevat ohutu; lihtlabane igavus ning teatav vahelduse otsimine ja vastuseis täiskasvanute organiseeritud mängudele; sõprade eeskuju: kõik ju teevad; poiste seas on sellel juures ka julguse näitamise maik; mängu kütkestav veidrus (Orro 2013: 13).

Elizabeth Tucker käsitleb lämmatamismänge kui laste üht viisi mõtestada küsimust elust ja surmast (Tucker 2009: 53). Iona ja Peter Opie tõstavad ohumängudes esile seda, et lapsed püüavad selle kaudu olla kindlad, et nad on oma valikutes ikka vabad. Tehes midagi, mida vanemad heaks ei kiida, saadakse kinnitust, et neid ei kitsenda vanemate määratud käsud-keelud. See on osa suurekskasvamise protsessist, kus tekitatakse närvikõdi, mis aitab lastel mõista riskeerimise olemust (Opie \& Opie 1984: 263). Niisiis toovad uurijad välja, et lapsed õpivad ohumängude kaudu riske võtma ja hindama.

Seda, miks lapsed tegelevad erinevate riskantsete tegevustega, on uurinud ka laste- ja arengupsühholoogid. Norra arengupsühholoogid Ellen Beate Hansen Sandseter ja Leif Edward Ottesen Kennair peavad riskimängude all silmas mänguvorme, mis on üles ehitatud nii füüsilisele kui ka emotsionaalsele eneseületusele, kus riski ja ohte mitte ei väldita, vaid püütakse neid ületada. Hirmu ületamine ja erutavate elamuste kogemine ongi mängu eesmärgiks. Erutavad elamused aitavad üle saada mitmetest kartustest, sel on foobiate-vastane toime (non-fobic effect). Neid tegevusi ja mänge, kus lapsed saavad oma hirme ületada, proovile panna oma füüsilisi ja vaimseid võimeid, on mitmesuguseid. Nende seas nimetavad uurijad tegutsemist ohtlike vahenditega, mis võivad põhjustada vigastusi ja haavu. Samuti toovad nad välja loodusnähtustega, nagu tuli ja vesi, seotud riskid. Riskide võtmine ja piiride kompamine kuulub teismeliste küpsemise ja eneseleidmise juurde. Ka koolieelikute kujunemine eeldab oma võimete testimist ja hirmutunde läbielamist (Sandseter \& Kennair 
2011). Folklorist Eda Kalmre on laste hirmujuttudele tuginedes märkinud, et nende juttude ja maagiaharrastuste usundiliste toimingute vahendusel lapsed sotsialiseeruvad, jaotatakse omavahel rolle, täiustatakse suhtlemisoskusi ning kasvatatakse usku oma võimetesse (Kalmre 2010: 14). Kindlasti on laste tegevuses problemaatiline see piir, millal hirm saavutab mängu ja lõbu üle võimu ning mäng ei olegi enam meelelahutus, vaid hirmuelamus. Samuti tuleb toonitada seda, et laste valmisolek riski võtmiseks ja ohutaluvus on erinev.

Niisiis on uurijad laste riskile ülesehitatud tegevusi ja mänge käsitlenud mitmeti, seda nii folkloristlikust kui ka arengupsühholoogilisest vaatepunktist. Kui võrrelda sõjamoonaga mängimist eelkirjeldatud mängude ja ettevõtmistega, võib seda kindlasti vaadelda kui riskile, põnevusele ja julgusele ülesehitatud tegevust, ükskõik kui adekvaatselt seda riski siis lapsena teadvustati või mitte. Samas sõltub sõjamoona mänguks rakendamine suures osas nii vahendite käepärasusest kui ka laste fantaasiast. Sel põhjusel ei loeks mina uurijana sõjamoonaga mängimist selliseks ohumänguks, mida eespool tutvustasin (nt "Jookse või sure"), vaatamata sellele, et nii sõjamoonaga mängimise kui ka ohumängudega on seotud risk ja oma julguse proovilepanek, samuti võib mõlemas mängimise ja meelelahutuse üle võitu saada hirmutunne.

Sõjamoonaga tegutsemist saab folkloristliku uurimise seisukohast paigutada mänguks konkreetsest mängukirjeldusest ja konkreetsest aegruumist lähtudes. Kui esiplaanil on mänguline tegevus ja seda kirjeldatakse pigem põnevusega (visati padruneid lõkkesse, tegevust paeplaadi tagant piiludes) ning kirjeldus on esitatud lastemängude kogumise võistlusele, loeksin ma kirjelduse julgelt mänguks. Kui aga eluloos räägitakse sõjamoonaga juhtunud õnnetustest, ei ole mõtet seda mänguna esitleda. Samuti ei ole hädavajalik painutada sõjamoonaga mängimise kirjeldusi ainult ühe või teise mänguliigi alla, kuigi neil on ühiseid jooni nii paugutamis-, ohu kui ka sõjamängudega.

\section{Kokkuvõte}

Artiklis esitleti sõjamängude teemat, tuginedes Eesti Kirjandusmuuseumi Eesti Rahvaluule Arhiivis 2013. aastal korraldatud lastemängude kogumise võistluse materjalile. Selle aluseks olevas uurijate koostatud küsitluskavas paluti mängukirjeldustele lisaks meenutada ka lapsepõlve üldisemalt: kirjeldada mängukeskkonda, mängupaika, -kaaslasi ja mängimise aega. Sõjamoonaga tegutsemise kohta küsimust küsitluskavas ei olnud, ent seitse vastajat tõid oma kaastöös selle teema mängimisega seostatult esile. Nende vastajate sünniaeg jäi ajavahemikku 1929-1946. Ilmneb, et sõjategevusest mahajäänud lõhkeainete ja relvadega mängimine on teema, mida mälestuste kirjutajad oma lapsepõlvest jagavad. 
Folkloristina vaatlen mängukirjeldusi kontekstualiseerimise kaudu, käsitlen mahajäänud sõjamoona kasutamist mänguvahendina kui sõja-aegsele ning -järgsele ajale iseloomulikku tegevust, mis levis teatud ajaloolis-kultuurilises ümbruses (Teise maailmasõja aegses ja järgses Eestis). Kõige sagedamini kirjeldatakse seda, kuidas erinevate lõhkevahendite abil paugutati, kuid mängimiseks kasutati erinevaid sõjamoona osasid, rakendades oma fantaasiat.

Mängimist põhjendatakse mitmeti, mängukirjelduse juures võidakse esitada oma täiskasvanu-ea seisukoht: tegemist oli ohtliku mänguga, sest lapsena kas ei teatud riskist või vastupidi, et osati riski hästi hinnata, samuti kolmas võimalus, et oldi lihtsalt hulljulge.

Sõjamoonaga mängimisel on ühiseid jooni nii paugutamis- kui ka ohumängudega. Kirjeldusi mitmesuguste vahenditega paugutamisest, aga ka püssirohu kasutamisest mängupüssides (nn susspüssides, sussikutes), leiab ka Eesti vanemas traditsioonis. Näiteks on lapsed karjas olles paugutanud söetükiga. Sõjaajast jäänud ja laste kasutusse jõudnud laskemoon andis võimaluse paugutamisvahendeid laiendada. Kirjeldusi laste mängimist mahajäänud sõjamoonaga, aga ka vanemate tagant kätte saadud lõhkematerjaliga, võib täheldada eri aegadest ning ka teistest maadest pärit allikates.

Ohumängude (ohtlike mängude), riskile ja hulljulgusele ülesehitatud mängude näiteid leiab mitmest lastemängude käsitlusest, neile on olemas paralleele nii rahvusvaheliselt kui ka tänapäeva mängude hulgas. Uurijad toovad erinevate ohtlike mängude mängimise tagamaana välja tahet kogeda riskivõtmist ja vastutust oma tegevuste ees. Mahajäänud sõjamoonaga mängimist saab samuti vaadata kui mänguviisi, kus pannakse proovile mängija uljus ja julgus.

Kirjeldustele tuginedes rakendasid lapsed sõjamoona abil oma leidlikkust, aga kogesid ka põnevustunnet. Samas võisid rohkete vigastuste ja õnnetuste tõttu sõjamoonaga seoses valdavad olla just vastupidised tunded. Nii seostub sõjamoonaga tegutsemine ühel osal sel ajal kasvanutel mängude ja uute mänguvahenditega, teistel aga kaotusvalu ja õnnetustega.

\section{Kommentaar}

1 Artikli valmimist toetasid Eesti Haridus- ja Teadusministeerium (IUT 2-43 "Traditsioon, loovus ja ühiskond: vähemused ja alternatiivsed diskursused" ja IUT 22-4 "Folkloor kultuurilise kommunikatsiooni protsessis: ideoloogiad ja kogukonnad") ning Euroopa Liit Euroopa Regionaalarengu Fondi kaudu (Eesti-uuringute Tippkeskus). 


\section{Arhiiviallikad}

\section{Eesti Rahva Muuseum}

KV - Eesti Rahva Muuseumi korrespondentide vastused

\section{Eesti Kirjandusmuuseum, Eesti Kultuurilooline Arhiiv}

EKLA f 350 - Eesti elulugude kogu (viidatud võistluse "EV 100. Minu elu ja armastus" käigus koostatud tabeli numbri järgi).

EKLA 350: 28 (2016/2017). Ain Erik (snd 1932), 18 lk.

EKLA 350: 87 (2016/2017). Juula Virroja (snd 1924), 31 lk.

EKLA 350: 120 (2016/2017). Uno Arula (snd 1931), $21 \mathrm{lk}$.

EKLA 350: 145 (2016/2017). Aavo Sirge (snd 1943), $121 \mathrm{lk}$.

EKLA 350: 179 (2016/2017). Harri Vilt (snd 1930), 23 lk.

\section{Eesti Kirjandusmuuseum, Eesti Rahvaluule Arhiiv}

\section{EFA - Eesti folklooriarhiivi rahvaluulekogu}

\section{ERA, DK - Eesti Rahvaluule Arhiivi digikäsikirjad}

\section{ERA - Eesti Rahvaluule Arhiivi rahvaluulekogu}

EFA I 168, 24/75 < Viru-Jaagupi khk, Vinni v, Võhu k < Iisaku khk, Lõpe k - Anu Soon, snd 1951. a (2013).

EFA I 168, 76/84 < Viru-Nigula khk, Aseri v, Rannu k < Abaja k - Selma Vasar, snd 1936. a (2013).

EFA I 168, 102/8 < Lääne-Virumaa, Väike-Maarja khk, Väike-Maarja al < Võnnusvere küla - Asael Truupõld, snd 1932. a (2013).

EFA I 168, 143/55 < Tartu linn < Keila khk, Keila linn < Tallinna linn - Hillar Palamets, snd 1927. a (2013).

EFA I 169, 1/30 < Põlva khk, Raiste k < Jämaja khk, Rahuste k - Leida Oeselg, snd 1934. a (2013).

EFA I 169, 31/7 < Saaremaa, Orissaare < Muhu khk - Elve Jäe, snd 1940. a (2013).

EFA I 169, 105/110 < Räpina khk, Kirmsi k - Ado Jõks, snd 1935. a (2013).

ERA, DK 106, 1- < Elva l < Valga l - Elvi Saar, snd 1946. a (2013).

ERA, DK 115, 1/19 < Pärnu l < Türi khk, Kurla k - Raivo Kaik, snd 1946. a (2013).

ERA, DK 121, 1/5 < Tartu linn < Valga, Valga 1 - Arvi Liiva, snd 1930. a (2013).

ERA, DK 127, 1/6 < Kadrina khk < Märjamaa, Haimre k-Anne Kurepalu, s. 1946. a (2013).

ERA, DK 134, 1/4 < Palamuse khk, Kuremaa < Kanepi khk, Krootuse - Ene Raudkats, snd 1943. a (2013). 


\section{Kirjandus}

Bauman, Richard \& Briggs, Charles L. 1990. Poetics and Performance as Critical Perspectives on Language and Social Life. Annual Review of Anthropology 19, lk 59-88 (doi: 10.1146/annurev.an.19.100190.000423).

Corsaro, William A. 2005. The Sociology of Childhood. Second edition. Thousand Oaks, London, New Dehli: Pine Forge Press.

Europaeus, Mikko \& Põlluäär, Aivo 2016. Children of Wartime. A Comparative Oral History Study of World War II in Finland and in Estonia. Tartu: University of Tartu.

Grauberg, Helena 2003. Mängimine ja keskkond. Mälestused lapsepõlvemängudest 1940.-1950. aastate Tartus. Runnel, Pille \& Sikka, Toivo \& Tammaru, Ivi (toim). Eesti Rahva Muuseumi aastaraamat XLVII. Tartu: Eesti Rahva Muuseum, lk 103-128.

Harju Elu 2017. Lapsed lõbustavad end ohtlike mängudega. Juhtkiri. Harju Elu, 17. märts (http://www.harjuelu.ee/lapsed-lobustavad-end-eluohtlike-mangudega/ 4. juuli 2018).

Hiiemäe, Mall 1998. Õitsilkäijate hooled ja rõõmud. Anepaio, Terje \& Jürgenson, Aivar (toim). Kultuuri mõista pü̈̈des. Trying to understand culture. Ajaloo Instituut, Scripta ethnologica 3. Tallinn: Teaduste Akadeemia Kirjastus, lk 176-195.

Hiiemäe, Mall (koost) 1999. Eesti rahvakalender VIII. Tallinn: Eesti Raamat.

Hinrikus, Rutt (koost) 2003. Eesti rahva elulood II. Sajandi sada elulugu kahes osas. Tallinn: Tänapäev.

Hinrikus, Rutt (koost) 2011. Sõjas kasvanud poisid. Eesti meeste mälestused sõjast ja Saksa okupatsioonist. Tallinn: Tänapäev.

Hvostov, Andrei 2014. Sillamäe passioon. Tartu: Petrone Print.

Kalliala, Marjatta 2006. Play culture in a changing world. Maidenhead: Open University Press.

Kalmre, Eda 2007. Hirm ja võõraviha sõjajärgses Tartus. Pärimuslooline uurimus kannibalistlikest kuulujuttudest. Tänapäeva folkloorist 7. Tartu: EKM Teaduskirjastus.

Kalmre, Eda 2010. Saateks. Kalmre, Eda (koost). Tulnukad ja internetilapsed. Uurimusi laste- ja noortekultuurist. Tänapäeva folkloorist 8. Tartu: EKM Teaduskirjastus, lk 1-16.

Kirm, Taivo \& Voltri, Ilmar 2016. Sillaotsa kool 1944-2016. Tartu: T. Kirm.

Korkiakangas, Pirjo 1996. Muistoista rakentuva lapsuus: Agraarien perintö lapsuuden työnteon ja leikkien muistelussa = The childhood of memory: the agrarian ethos in the work and play. Helsinki: Suomen Muinaismuistoyhdistys.

Kross, Jaan 1987. Vastutuulelaev: Bernhard Schmidti romaan. Tallinn: Eesti Raamat.

Kulli, Jaanus 2013. Toivo Tootsen: "RAMETO toimetus oli perekond, mis kestis 30 aastat. Selle aja jooksul vahetas enamik meist oma päris perekondi”. Õhtuleht, 26. oktoober (https://www.ohtuleht.ee/551218/toivo-tootsen-rameto-toimetus-oli-perekond-mis-kestis30-aastat-selle-aja-jooksul-vahetas-enamik-meist-oma-parisperekondi--21. juuni 2018). 
Laine, Martin 2017. Koolitöötaja sattus tunnistajaks "Jookse või sure" mängule. Pärnu Postimees, 12. märts (https://parnu.postimees.ee/4042923/koolitootaja-sattustunnistajaks-jookse-voi-sure-mangule - 4. juuli 2018).

Michelson, Helen 2017. Ohtlik enesetapumäng "Jookse või sure” jõudis Kuressaarde. Postimees, 9. märts (https://www.postimees.ee/4039509/ohtlik-enesetapumang-jooksevoi-sure-joudis-kuressaarde - 4. juuli 2018).

Mulla, Triin 2003. "Minu õnnelik-rahutu lapsepõlv": 1940. aastad eestlaste lapsepõlvemälestustes. Kõresaar, Ene \& Anepaio, Terje (toim). Mälu kui kultuuritegur: etnoloogilisi perspektiive. Studia Ethnologica Tartuensia 6. Tartu: Tartu Ülikooli Kirjastus, lk 92-123.

Opie, Iona \& Opie, Peter 1984. Children's Games in Street and Playground. Oxford \& Ney York: Oxford University Press.

Orro, Iti-Liis 2013. Lämmatamismäng Eestis 1980. aastatel või hiljem sündinute meenutuste näitel. Seminaritöö. Tartu: Tartu Ülikool (http://mobile.dspace.ut.ee/bitstream/ handle/10062/35344/orro_sem_2013.pdf?sequence=1\&isAllowed=y - 21. juuni 2018).

Paksuniemi, Merja \& Mättä, Kaarina \& Uusiautti, Satu 2015. Childhood in the shadow of war: filled with work and play. Children's Geographies 13 (1), lk 114-127 (doi: 10.1080/14733285.2013.828452).

Päästeamet 2018. Lõhkeaine või lahingumoona leid. Päästeameti koduleht (https://www. rescue.ee/et/kodanikule/plahvatusoht/lohkeaine-voi-lahingumoona-leid.html - 21. juuni 2018).

Raigna, Raivo 2012. Asael Truupõld - mida Juhan ei tea, seda ei saagi Juku teada. Virumaa Teataja 7. juuni (https://virumaateataja.postimees.ee/868890/asael-truupoldmida-juhan-ei-tea-seda-ei-saagi-juku-teada - 21. juuni 2018).

Sandseter, Ellen Beate Hansen \& Kennair, Leif Edward Ottesen 2011. Children's Risky Play from an Evolutionary Perspective: The Anti-Phobic Effects of Thrilling Experiences. Evolutionary Psychology 9 (2), lk 257-284.

Tallinna linna koduleht 2017 = Internetis levivad ohtlikud väljakutsemängud lastele. Tallinn.ee 15. märts (https://www.tallinn.ee/est/Uudis-Internetis-levivad-ohtlikudvaljakutsemangud-lastele -4 . juuli 2018).

Tucker, Elizabeth 2008. Children's Folklore: A. Handbook. Westport (Conn): Greenwood Press.

Tucker, Elizabeth 2009. "Go to bed, now you're dead": suffocationsongs and breath control games. Children's Folklore Review 31, lk 45-57 (https://scholarworks.iu.edu/ dspace/handle/2022/13614 - 21. juuni 2018).

Uka-uka 2013 = Uka-Uka. Vanad ja uued mängud rahvaluulearhiivis. Eesti Kirjandusmuuseumi Eesti Rahvaluulearhiivi mängude lehekülg (http://www.folklore.ee/ukauka/_ 21. juuni 2018).

ÕS 2013 = 'sutspüss'. Erelt, Tiiu \& Leemets, Tiina \& Mäearu, Sirje \& Raadik, Maire (koost). Eesti õigekeelsussõnaraamat (http://eki.ee/dict/qs/index.cgi?Q=sutsp\%C3\%BCss 21. juuni 2018). 


\title{
Summary
}

\section{Estonian children's games using munitions during and after World War II}

\author{
Astrid Tuisk \\ Researcher, Estonian Folklore Archives, Estonian Literary Museum \\ astrid.tuisk@folklore.ee
}

Keywords: children's folklore, children's games, contextualization, dangerous games, post-war period, World War II

Children who lived in the WWII and post-war period, under the occupation of Nazi Germany (1941-1944) and the Soviet Union (1944-1991), had their own assortment of games. Estonia suffered the fate of being on the battlefront twice - in 1941 and 1944. Among the traces of war that inspired children's games were munitions scattered around the terrain.

In 2013, the Estonian Folklore Archives of the Estonian Literary Museum organised a competition for collecting children's games. In this paper, I examine the accounts about playing with munitions - mainly cartridges found on the terrain and real gunpowder collected from people born in the period between the late 1920s and late 1940s.

From a folkloristic perspective, I study the descriptions of games collected in the competition in two ways. First, I situate them in their historical-cultural context. The use of left-behind munitions for playing was characteristic of WWII as well as the post-war period and mostly typical of boys. The descriptions emphasise spectacular fireworks and loud cracking. The use of various means (e.g. glowing embers by children herding animals) for making loud sounds, but also real gunpowder in toy guns (sussik in Estonian) was also present in the earlier tradition.

Although the respondents might not have perceived the risks associated with these activities back when they were children, their descriptions usually also include their adult point of view: these games were very dangerous. Some claim that they were not aware of the risks; others that they were able to assess them well; still others that they were simply foolhardy. The descriptions of games also reveal a certain perplexity - adult respondents are at a loss to explain why they did those things as children.

Left-behind munitions could be obtained quite easily, while conventional toys or means for making them were severely lacking at the time. Thus, children played with whatever they could find and the use of munitions diversified the range of toys available to them.

Secondly, I interpret the games with left-behind munitions as a type of game that tests the daring and foolhardiness of players. Dangerous games and risky-play games are discussed in several accounts of children's games. Researchers suggest that playing dangerous games is driven by the will to make sense of risk-taking and responsibility. Child and developmental psychologists find that such games are characteristic of childhood and adolescence, and that playing them is necessary for normal development. Children's risktaking behaviour and testing the boundary between the possible and impossible is an integral part of coming of age and self-realisation during adolescence. Yet, development in the preschool age likewise implies testing one's capabilities and experiencing the feeling of fear.

Munitions were novel and fascinating, and enabled children to apply their inventiveness, sense their bravery, and experience excitement. On the other hand, due to frequent injuries and accidents, one could also find exactly the opposite attitudes toward munitions. Thus, for some people who grew up in that era, munitions are associated with games and new toys, but for others, they are associated with pains of loss and tragedy. 